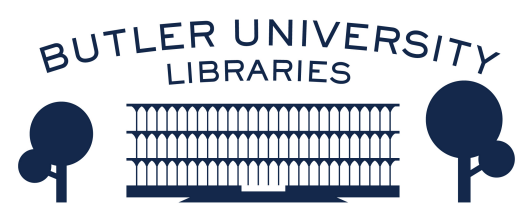

Journal of Hindu-Christian Studies

Volume 23

Article 6

January 2010

\title{
Suffering Savior - A Hindu Vaisnava Perspective
}

K.R. Sundararajan

Follow this and additional works at: https://digitalcommons.butler.edu/jhcs

Part of the Religion Commons

\section{Recommended Citation}

Sundararajan, K.R. (2010) "Suffering Savior - A Hindu Vaisnava Perspective," Journal of Hindu-Christian Studies: Vol. 23, Article 6.

Available at: https://doi.org/10.7825/2164-6279.1458

The Journal of Hindu-Christian Studies is a publication of the Society for Hindu-Christian Studies. The digital version is made available by Digital Commons @ Butler University. For questions about the Journal or the Society, please contact cbauman@butler.edu. For more information about Digital Commons @ Butler University, please contact digitalscholarship@butler.edu. 


\title{
Suffering Savior - A Hindu Vaiṣnava Perspective
}

\author{
K. R. Sundararajan \\ St. Bonaventure University
}

MY interest in inter-religious dialogue goes back to the late sixties when I was a research student working on a doctoral dissertation on "The Doctrine of Incarnation in Hinduism and Christianity" and continued when I became a Lecturer in Hindu Studies at the very first department of Religious Studies in India at Punjabi University in Patiala. From there I was brought to the Harvard Center for the Study of World Religions as a Fellow by Professor John Carman to take courses in Christian Studies at the Harvard Divinity School for three years from 1970 to 1973 . It was a period when Dr: Wilfred Cantwell Smith returned to the Center to be its director. My approach to interreligious dialogue was largely shaped by Dr. Cantwell Smith, whose writings had a great impact on me, especially his emphasis on person and faith as the context of interreligious encounter and understanding. These have been validated in my own life where my understanding and appreciation of Islam, Christianity, and Sikhism were largely shaped by my colleagues in the department of Religious Studies with whom I was able to develop deep personal relationships as friends. The level of friendship operates in two ways: first, It impacts "existentially," with friends not simply remaining as the distant "other" but as those shaping one's personal and social relationships; and second, religiously, relationships with friends from "other traditions and faith" results in a greater understanding and appreciation of one another, so that socially and culturally inherited labels of exclusion and ridicule fail to be meaningful. I see this friendship model essential to interreligious dialogue where the participants are not simply interacting with one another out of curiosity, intellectually sharing with one another theological and practice-oriented aspects of their respective traditions, but are drawn out of "necessity," so to speak, to learn and be "benefited" by mutual sharing and understanding of one another. This is the "existential" dimension of interreligious dialogue where the participants do not come fully convinced that there is nothing significant religiously or intellectually from other traditions. As a Hindu, I personally feel "challenged" by the legacy of Jesus Christ, the uniqueness of his incarnation as well as by his being the "suffering savior" redeeming humankind through his suffering and death. These aspects. I find challenging, since at one level the Hindu

Dr. K. R. Sundararajan is currently Professor of Theology at St. Bonaventure University in New York State. He received his Ph.D. from the University of Madras (1967) and was at the Center for the Study of World Religions, Harvard University, as a Post-Doctoral Fellow (1970-73). He was a Lecturer in Hindu Studies at the Punjabi University, Patiala from 1967-75. He joined the faculty of the Department of Theology, St. Bonaventure University in 1975. He was one of the participants in the multi-religious dialogue sponsored by the World Council of Churches in 1974 and has attended a variety of other conferences and seminars throughout the U.S., Canada, Europe, Africa, and India. He is widely published, with numerous articles in academic journals in the USA, UK and India, along with contributed chapters to a number of books. He has edited the second volume of Hindu Spirituality-Post Classical and Modern in the "World Spirituality" series. His publications are in the following areas: Hinduism; Theistic Vedanta and Vaishnavism; Comparative Studies: Hindu and Christian; Indian and Chinese Religions; Interreligious Dialogue. He also served as a Senior Academic Advisor to The Hindu Encyclopedia Project for several years. 
tradition has no place for a unique incarnation or the suffering of God. But with my studies of the Christian tradition I know that these claims are made seriously, and they cannot be brushed aside or "watered down," if I have to deal with Christians either in an interreligious dialogue or at a personal level of friendship. I feel that in order to interact meaningfully with participants of other religious traditions in dialogue, each of us should have some degree of scholarly knowledge and understanding of the traditions of the participants. From this angle, scholars in the field of Comparative Study or History of Religions would be better choices for interreligious dialogue.

I had interacted with several Christian seminarians and scholars during the time when I was doctoral student at the University of Madras. In the Madras area itself I met a few Protestant theologians with whom I discussed the topic of my doctoral work and from whom I sought help in directing my further studies. I had also spent a month living. among Catholic seminarians, students and professors in Poona (Pune) while I was using the resources of their library. When I returned from Harvard in 1973 to Punjabi University to resume teaching I was invited to give a lecture on the topic of "A Hindu view of Jesus". at a Jesuit seminary in Delhi. My preséntation was well received, and thereafter I continued to visit the institution for several years. This paper was published in the journal of The Unitarian Universalist Christian in 1974 under the series "Jesus through other eyes." I was later invited to give a series of lectures on Hinduism at a Catholic Seminary (Sacred Heart College) located in Shenbaganur in Madras State (now moved to the city of Madras), and here I lived in the seminary itself for a month lecturing twice a week actively interacting with students and professors.

In "A Hindu View of Jesus" I discussed the dynamics of interreligious dialogue in terms of a twofold process of "appropriation" and "appreciation." This is what "understanding" includes in the context of dialogue. To "understand" Christ, a Hindu invariably "Hinduizes" Christ as did many of the thinkers of the Modern Hindu period, using indigenous Hindu categories, as, for instance, "avatāra" (divine incarnation) and its divine-human dimensions. This is what I have stated as "appropriation," where the "other" is understood in terms of categories of one's own. Here, the "other" ceases to be the other, as it did for Keshub Chandra Sen, who claimed Jesus to be Asiatic, perhaps more in terms of being "Indian." "Appreciation" is the complementary process, which finds its place in the context of those religious and spiritual components that could not be thus appropriated and indigenized. Appreciation becomes fully operational when we come to see these "other-ly" aspects within the context of the respective tradition recognizing their place and importance. In order to do so, one needs familiarity and some degree of scholarship in these dialoguing religious traditions, just as in order to "successfully appropriate" one needs to be familiar with a broad range of things that one's own tradition includes and a scholarly understanding of at least one of the schools or areas within its broad spectrum. In an essay published in the Journal of Ecumenical Studies (Spring 1986), "Hindu Models of Interreligious Dialogue," I have described a "border-crossing model," as best suited to a meaningful and fruitful interreligious dialogue. Religious dialogues are occasions for both learning as well as personal enrichment. While in the process of learning about other religious traditions we invariably cross borders, in terms of personal enrichment, we integrate and internalize what we have learned through our "journey", and this is through appropriation and appreciation. A successful and fruitful appropriation is accomplished first, by being open, and second, by a willingness to expand and stretch out the limits of one's traditional boundaries to find and establish connections, and this may require that we explore avenues within our own tradition that we have not explored before. These border-crossings in dialogue are done at the invitation of "other participants" with their guidance and direction. There is a personal enrichment here in terms of our understanding of the "other" tradition as well as of our own tradition. The knowledge of other traditions and personal interaction with those who belong to them have the effect of gaining a deeper understanding of our own 
tradition. A recent book by Arvind Sharma, Islam for Hindus (2009) is indeed a good example of finding connections between these two traditions and thus enabling a deeper understanding of them, and I personally feel that works of this kind are needed to foster interreligious understanding. Like the thinkers of Modern Hinduism, I believe that there are universal and common components in all religions, which facilitate the task of finding connections and viewing one's own conceptual framework in a broader and universal perspective.

Historically, it is true that border-crossings have also been done outside the context of interreligious dialogue, often leading to a simple" annexation." A tradition tends to "soften" the challenges posed by "other traditions" often through integration, whereby the alien becomes native and indigenous. This can be seen in the case of Vedānta encounters with Buddhism, particularly in Gaudapāda, who was the grand preceptor of Śankara and a pioneer if not the "founding father" of Non-dual Vedānta (Advaita). He had been accused of being a "Buddhist in disguise" by his critics for the reason that his formulation of non-dual Vedānta betrayed the influence of Buddhist metaphysics. He, however, seemed to have denied this by saying: "This was not spoken by the Buddha." Surindranath Dasgupta, a wellknown modern historian of Indian philosophy, reasons that what Gaudapāda meant by this statement of denial was that the teachings of the Upanișads tallied with those of the Buddha, and hence there was no need to acknowledge the Buddhist influence on him! This sort of unacknowledged annexation is mostly the way that the mainstream Brahmanical tradition in Hinduism sought to integrate and incorporate into it the outside influential and popular traditions in the Indian scene. This is seen by many as the virtue of "Hindu tolerance."

Now coming to the topic of this paper, "Suffering Savior - A Hindu Vaiṣnava Perspective" my doctoral work on comparative studies focusing on the doctrine of divine Incarnation not only made me deal with the issue of a Hindu view of Jesus, but also wrestle with the question of the spiritual efficacy of suffering and death that Christology highlighted. From a general Hindu perspective the notion of suffering savior does not make sense, since suffering and death are essentially dimensions that belong to the human whose life is governed by the twin principles of karma and samsāra. The Divine Being even in its incarnate state is free from samsāra and hence exempt from "real" suffering and death. However, this may not be true if we look at the human incarnations from the angle of popular Hindu piety that is shaped largely by the epics and purānas, where the "human side" of the incarnate being is as much highlighted as its divine side. The story of Rama, for instance, narrated in the early version of the epic Rāmāyana, presents a "hero" who is subject to ignorance and suffering, though finally triumphing over these human conditions and limitations. While this may suggest some compatibility with the theme of suffering savior, the exploration of the theological dimensions become essential in order to further strengthen and complete the task in an interreligious dialogue. Here, I am eager to explore and examine the resources of the Hindu tradition, conditioned largely by my interest and specific research orientation, the Rāmānuja and postRāmānuja schools of Vaiṣnavism.

It is interesting to see that the Hindu schools of devotion, particularly of Rāmānuja, remained also the focus of interest for several modern Indian Christian theologians to work out a comparable Christology. S.J. Samartha, writes:

It is sometimes argued that in the context of India's religious thought the theistic advaita of Rāmānuja, with its emphasis on bhakti (loving devotion to a personal God) is more suited to workout a Christology than any other system of thought. H. Kraemer, Rudolf Otto, A.J. Appasamy and many others have felt that bhakti categories are particularly useful to explain the incarnation. Appasamy has without hesitation described Christianity as bhakti märga (the way of devotion) and Chakkarai has called Jesus the avatar. The doctrines of God and the incarnation in the Hindu bhakti tradition are claimed to be closer to the Christian understanding, than any other. ${ }^{1}$ 
Brahman or Viṣnu, the Supreme Being, in Rāmānuja's theology is both transcendent as well as immanent and His immanence is often described in terms of His easy accessibility to the jīvas. Easy accessibility accounts for acts of "graceful condescension" of the divine. John Carman points out that in the Vedānta of Rāmannuja there are two different kinds of relationships between God and the individual selves (jīvas). In the first relationship, God presides over the working of the law of karma without interfering in people's moral decisions and religious activities. In the second relationship God actively intervenes, both in the life of individuals and in the affairs of the world as a whole, ${ }^{2}$ and acts of graceful condescension follow this relationship. God's relationship in terms of His "condescending grace" remain the focus in the post-Rāmānuja Southern Vaiṣnavism. Here Vișnu's condescending acts of grace often seem to triumph over or override his transcendence. According to these schools, Śrī, the consort of Viṣnu, plays the role of a mediator between God and the jīvas in samisara. Pillai Lokācārya in Śrīvacana-bhūṣana, describes the mediator role of Śrī thusly:

She joyfully submits herself to İ́vara, as she has her being in Him and belongs to Him, and always intercedes on behalf of the sinner by pleading for his being forgiven. On the one hand, she subdues the retributive will of Î́vara by the beauty of her enticing love and on the other, she melts the heart of the sinner by her infinite tenderness. ${ }^{3}$

It is to be noted that though there are differences between the two Southern schools of Vaiṣnavism, Tenkalai and Vaḍakali, on the status of Śri, both insist that her grace $(k r p \bar{a})$ is essential to salvation. According to Srinivasachari, as divine mediatrix "she intervenes between the sinner and the Holy and transforms the former into mukta and the latter into the Savior."

On the question whether God is 'obligated' to save humankind in samsāra, there are differences between Rāmānuja and postRāmānuja schools of Vaiṣnavism. According to Carman, this is the issue of the conditional or the unconditional nature of divine grace, where Rāmānuja"s preference is for "conditional grace" and the choice of post-Rāmānuja schools for "unconditional grace" (nirhetuka krpā). The theology of Rāmānuja necessarily emphasizes the theme of pleasing God through the servantmaster (śeșa-śeși) relationship where the jīva, by his service to the Lord, wins His favors and thus "obligates" the Master to care for the (spiritual) welfare of the servant in return. However, in post-Rāmānuja Śñ-Vaiṣnava theology the same need of the superior or master to take care of his servants arises when the servant acknowledges his inability to care for himself and has shown his utter dependency on the Master by the (ritual) acts of self surrender (prapatti). ${ }^{5}$ The conditional nature of Divine grace in Rāmānuja seems to suggest that while there is no necessity; God, by the virtue of his nature, is favorably disposed to save humankind.

In contrast to Rāmānuja, we find that postRāmānuja schools of Vaiṣnavism tend to tilt the balance in favor of the notion that God is "obligated" to save humankind, though perhaps at the initiative of Srī. The Tenkalai tradition especially stresses the unconditioned nature of divine grace not stressed by Rāmānuja himself, as we have seen. The qualities $k x p \bar{a}$ and vātsalya (filial attachment) tend to be emphasized in the description of divine nature and therefore the ideal model of relationship between God and individual selves becomes more "familial" instead of being one of servant-master. It is interesting to note that while the Vadakalai defines the effect of vātsalya (filial love or attachment) in the divine nature as the removal of dosa (defects) and cleansing of the soul, the Tenkalai sees it as something where vātsalya connotes also delight in doșa. It is the nature of divine forgiveness to welcome the sinner and not to penalize him for wrong doing. ${ }^{6}$ In the Tenkalai tradition, where divine grace (dayâ) is pushed to its limits, the savior God enters and even experiences the sorrows of humankind (paraduhkhe duhkhitvam). ${ }^{7}$ Therefore, the Tenkalai comes closest to the Christian concept of suffering savior, with God experiencing the suffering of humans and redeeming them by his grace. Still whether such a suffering on the part of the Supreme Being, Viṣnu, has any 
redemptive implication is not clear. This possibility of God sharing and experiencing suffering that rightfully belongs only to humans has been hinted at by Vedānta Deśika, an eminent post-Rāmānuja theologian of the Vadakalai school in one of his minor works. In Dayāśataka he exalts the graceful role of Śrī as the mediator between God and those jīvas in bondage. Here we read: "O Dayā, it is at your instruction that the Lord Śrinivāsa [Viṣnu] by his $l \bar{l} l \bar{a}$ takes many births in the place of those who have surrendered to him and bears the disgrace that had been inflicted on Him by the foolish and ignorant ones" (35). This verse is interesting since it suggests that the purpose of divine incarnation is in some way connected with the lives of His devotees who have performed prapatti (self-surrender) and thus been freed from samisara. God is incarnated in human form to exhaust the unexhausted prārabdha karmas of the prapannas (those who have surrendered) and in that situation opens himself to experiencing pain and disgrace. The notion of "merit transfer" remains very much a part of the popular Hindu piety. For instance, a householder hopes to "gain" some of the good karma of a sannyāsi when he or she feeds him. However, Vedānta Deśika in the above verse from Dayāśataka seems to suggest an unusual way of disposing of the leftover prārabhda karma, good and bad of the prapanna, which I feel, provides an opening for a Hindu understanding of the Christian notion of vicarious suffering! However, the Christian concept of redemption through vicarious suffering and death is difficult to fit into a Hindu and Vaiṣnava framework. Even the Dayāśataka passage that I have cited above could not be read as God redeeming the prapanna by voluntarily assuming his leftover unspent karma (prārabhda) and living through it. The linking of suffering with redemption is lacking here. There is no compulsion on the part of God to incarnate for this purpose -- it is His $\bar{l} \vec{l} \vec{a}$, and He could act in other ways, for instance, by redistributing the good karmas to the well-wishers of the prapanna and bad to his enemies. However, the very fact of his "condescending grace (sausinllya)" shows that He indeed empathizes with the suffering and limitations of the jīvas in samisāra, and feels "obligated," at least in Tenkalai and Vaḍakalai schools of Vaiṣnavism, to save them from their condition. God's humanity is essentially related to His "accessibility (saulabhya)," expressed in acts of "condescending grace," and both Rāmānuja and post-Rāmānuja schools lay equal emphasis on both easy accessibility and transcendence (paratva). Carman points out that in the theology of Rāmānuja these two essential attributes of God are seen as both complementary as well as tensional, balancing one another and accounting for the livelines's of his Vedānta. ${ }^{8}$ This "balancing of the opposites" gets lost in the post-Rāmānuja Śri-Vaiṣnavism where the attributes of accessibility comes to be more heavily emphasized than divine transcendence. Here, the model of relationship shifts from that of a master-servant/slave to a parent-child, from a power-based relationship to a filial-based relationship as we move from Rāmānuja to post-Rāmānuja Vaiṣnavism. Religious piety seems to demand a condescending God who descends to the human level to alleviate the sufferings of the jivas, but interestingly enough, the success of such an enterprise, at least in the mind of the devotee, is enabled by divine transcendence. Again in terms of religious piety, the notion of "divine suffering," as for instance, in the story of Rāma, fosters a sense of "fellowship with God," gives sense and meaning to human life.

To sum up: while it is possible to find traces of vicarious suffering in the Vaisnava schools, the redeeming power of suffering is not to be found. Using the dynamics of appropriation and appreciation, a Hindu should be able to "domesticate" and even "Hinduize" the notion of vicarious suffering in spite of strictly theological problems that it raises, the correlation of suffering and redemption remains outside the purview of appropriation, however central it is to Christian faith. From a Hindu participant who is familiar with Christian tradition and faith this correlation demands "appreciation," as it continues to challenge the participant both academically as well as spiritually. 
14 K. R. Sundararajan

\section{Notes}

1 The Hindu Response to the Unbound Christ (Madras: Christian Literature Society, 1974), pp. 162-163.

${ }^{2}$ John Braisted Carman, The Theology of Rāmānuja: An Essay in Interreligious Understanding (New Haven and London: Yale University Press, 1974), p. 176.

${ }_{3}$ P. N. Srinivasachari, The Philosophy of Višiștadvaita (Madras: Adyar Library and Research Centre, 1978), p. 524.

${ }^{4} \mathrm{Ibid}_{2}$, p. 537.

${ }^{5}$ Carman, The Theology of Rāmānuja, pp. 178-179.

${ }^{6}$ Srinivasachari, The Philosophy of Viśisțtadvaita, p. 538.

${ }^{7}$ Ibid.

${ }^{8}$ The Theology of Rāmānuja, p. 87. 